\title{
Offer Document Disclosures and Its Impact on Equity Return in India
}

\section{Dr. Swinder Singh}

Associate Professor and Head,

PG Department of Commerce and Business Management

Guru Nanak College, Sukhchainana Sahib, Phagwara, Punjab, India.

\begin{abstract}
Primary market investors deploy their surplus funds in equity issues on the basis of disclosures made by the issuer companies in their offer documents. An attempt has been made in the present study to measure the impact of offer document disclosures regarding turnover, total assets, net worth, earnings per share, book value, percentage of dividend paid, age, promoters' stake in post-issue capital and issue size on equity return in India. Taking a sample of 97 equity issues of the size of Rs. 10 crore or more of closely held unlisted companies belonging to 5 different industries during a period of 12 years from 199293 to 2003-04 and after applying Linear Multiple Regression Analysis, the study finds that the offer document disclosures covered by the study explained significant amount of variation in equity return in case of issues of banking as well as finance and investment industry. Disclosure of turnover in case of issues of finance and investment industry and of net worth and earnings per share in case of issues of pharmaceutical industry established its statistically significant impact on equity return during the period covered by the study. The industry-wise performance revealed that the equity issues of banking industry proved more beneficial for long-term investors whereas the issues of IT industry remained more profitable for short-term investors. The study reported that the equity issues of finance and investment industry provided less initial return and highest negative return to the investors after three years from first trading day of the issues on Bombay Stock Exchange.
\end{abstract}

Keyword: Earnings per Share (EPS), Stock Split Adjustment Factor (SSAF), BSE, NSE, SEBI, FII

\section{INTRODUCTION}

Offer document is issued by a corporate body for mobilization of funds through public and rights issue of different types of securities in the primary market. It is like a window through which a prospective investor looks at the strengths and weaknesses of the issuer company and commits his surplus funds to the pool of resources being mobilized for certain specific objects mentioned therein. The issuer company drafts its offer document following relevant provisions of The Companies Act, 1956 and Disclosure and Investor Protection (DIP) guidelines issued by the Securities and Exchange Board of India (SEBI). Through offer document disclosures, an issuer company not only provides information about its proposed project but also about its past financial performance, operating results and current state of affairs. Disclosures provide a solid base to a decision maker to take an informed investment decision.

SEBI's DIP guidelines require an issuer company to make disclosure in the offer document with respect to the present issue, its objects, project cost, means of finance, name of the appraising institution, structure of share capital including promoters' contribution in the proposed issue and their stake in the post-issue share capital, background of promoters, past financial performance and of all adverse events for the information of the investing public. Section 56 of Companies Act, 1956 states that an issuer company is required to disclose its audited 
financial results for five years preceding the year of public issue in the offer document. Financial results are disclosed under the heading 'Past Financial Performance' which include information about total assets, turnover, Profit Before tax (PBT), Profit After Tax (PAT), Earnings Per Share (EPS), Book Value (BV) / Net Assets Value (NAV), net worth, dividend paid etc. Some of these financials are also shown under the heading 'Basis for the Justification of Issue Price' in the offer document. From among the disclosures of offer document, the disclosures of financial nature such as turnover, total assets, net worth, EPS, book value and dividend history of the issuer company are given more weightage by the investors at the time of their investment decision. Besides this, an informed and wise investor also gives importance to disclosure regarding promoters' contribution in the proposed issue and their stake in the post-issue capital, age of the company and size of the issue. A brief description about these disclosures cum decision factors is given below.

Turnover/Operating Revenue of the issuer company during a particular period reveals the efficiently with which resources of the business have been employed by the management. A track record of growing turnover with cost under control lays the foundation of good profitability position of the company.

Total Assets represent the application of total resources generated by a company. Investment is always preferred in the equity of that company which has strong assets base. Total assets are equal to total of fixed assets (after depreciation) plus current assets. Fictitious assets are not taken for finding out total assets as they are deducted from net worth for all financial decisions. Considering the importance of assets base, SEBI revised its DIP guidelines on $14^{\text {th }}$ August 2003 and introduced new criterion of net tangible assets as a pre-condition for floating a public issue which requires that the issuer company should have net tangible assets of at least Rs. 3 crore for three complete years of which not more than 50\% should be held in monetary assets (cash or cash equivalent).

Net Worth means the funds belonging to the owners of the issuer company. A high net worth is an indicator of good financial position, large stake of owners in the business and provides more safety to the creditors of the company. Disclosure of net worth provides an opportunity to the prospective investors to know about the financial soundness of the issuer company. SEBI's DIP guidelines require the issuer company to have a minimum pre-issue net worth of Rs. 1 crore in 3 out of 5 preceding years as one of the conditions for floating a public issue. Net worth, as defined in SEBI's DIP guidelines, is calculated as follows:

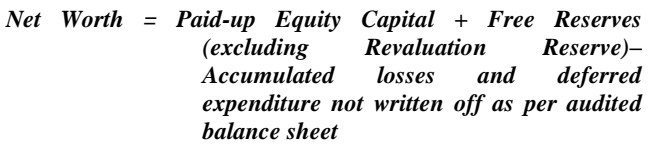

Earnings per Share (EPS)Equity shareholders are the real owners of a company and all earnings after the payment of taxes and preference dividend (residual earnings) belong to them. The finance and investment experts consider EPS as most important indicator of financial performance of a company. Higher EPS shows good financial performance on one hand and provides scope for higher dividend pay-out on the other hand. This ratio, when multiplied with the price earnings ratio gives an estimated figure of the issue price of the shares to the company. When the same ratio is multiplied with the price earnings ratio of the industry/peer group, it gives an idea of possible appreciation/gain to the investors on listing of shares on a stock exchange. Numerically, it is computed with the help of following formula:

$$
\text { EPS }=\frac{\text { Earnings after Taxes \& Pref erence Divident }}{\text { Number of Equity Shares outstanding }}
$$

Book Value (BV) Per Share: Book value or net asset value per share shows the value of assets per equity share which are owned by the company on behalf of its equity shareholders. The book value is equal to the excess of total assets over total liabilities. It is the amount of net assets that would be available per equity share after a company pays off all liabilities including preference share capital from the sale proceeds of all its assets liquidated at balance sheet values. Book value is one of the main indicators which reflect the performance of the company in the past. Higher the book value, safer will be the investment in the company and 
vice-versa. Disclosure regarding book value in the offer document provides an insight to the prospective investors about the profitability of the company and efficiency of the management in the past. It is computed as follows:

\section{Book Value per share}

Value of Assets owned by Equity Shareholders Number of Equity Shares outstanding

Percentage of Dividend Paid: Dividend is an allocation of profits for equity shareholders of the company. It is paid as some percentage on the paid-up capital of the company or as some fixed amount per share or certain percentage of net earnings distributed as dividend depending upon the dividend policy of the company. Though, a company is not legally bound to pay dividend every year but majority of the shareholders always desire that the company should pay some dividend on their investment. A track record of good dividend pay-out is a positive factor which incites the investors for making fresh investment in the equity of the company. Percentage of dividend paid on paid-up capital of the company is calculated as given below:

\section{Percentage of Dividend Paid $=\frac{\text { Total Amount of Equity Dividend Paid }}{\text { Paid-up Equity Capital of the company }} \times 100$}

Promoters' Stake in Post-Issue Capital: SEBI's guidelines require some minimum participation of promoters in the public issue which is $20 \%$ of the post-issue equity capital in case of public issue by an unlisted company and in case of offer for sale, the promoters' contribution after offer for sale shall not be less than $20 \%$ of the post-issue equity capital. In case of public issue by listed company, the promoters are required to participate either to the extent of $20 \%$ of the proposed issue or to ensure post-issue shareholdings to the extent of $20 \%$ of the post-issue equity capital. Besides this, promoters are free to make additional contribution in the public issue and their stake in the post-issue capital can be more than the minimum required under the guidelines. Higher share of promoters in the public issue as well as in the post-issue capital binds them with the company to work hard for the achievement of the issue objects. Promoters' minimum contribution is locked for a period of 3 years from the date of allotment or date of commercial production, whichever is later. The additional contribution of promoters is also locked for a period of one year. Investment in the public issue with higher stake of promoters in post-issue capital is certainly less risky and safer than in the public issue with less promoters' stake.

Age of the Issuer Company: The age of the issuer company refers to the period, in complete years, from the date of incorporation to the date of the opening of the public issue. Investment decision is also influenced by the age of the issuer company. During capital market fall of 1995, it was found on investigation that many new companies promoted by inexperienced promoters raised huge funds from the market and later on majority of them could not deliver, some fled away with investors' money and a few of them vanished or did not set-up the projects for which funds were mobilized (Jain, 2001). There are no two opinions that a new company has to face more challenges to create market for its products/services and to win over the confidence of its investors. Financial advisors always recommend to make investment in the public issue of that company which has done considerable business, known to public through market exposure and has influenced the investors through its performance. Disclosure regarding date of incorporation of the company and date of opening and closing of the issue facilitate the investors to find out the age of the issuer company.

Issue size: Size of the issue is stated on the first page of the offer document in a fixed price issue whereas it becomes known after the completion of the bidding process in a book built issue. In a book building issue, the number of equity shares and the price band mentioned in the offer document provide a rough idea about the size of the issue.

\section{REVIEW OF LITERATURE}

A number of studies have been conducted in India and abroad to study various aspects of primary capital market from different angles and brought to light both positive and negative aspects which need the attention of the policy makers, the 
regulatory bodies, the players of the market and finance experts.

Foreign Studies: Most of the foreign studies on primary capital market are focussed on measuring the underpricing of Initial Public Offerings (IPOs) on listing day. The studies conducted by Ibbotson (1975), Ritter (1984), Fernandez et al. (1993), Loughran (1994), Akhtar and Quddus (1999), Arosia et al. (2000) and Kooli (2001) revealed underpricing with different degrees in Initial Public Offerings. Some studies have also been carried out to measure the short-run and long-run performance of Initial Public Offerings (IPOs). The research work done by Rock (1986), Ritter (1991), Levis (1993), Sullivan and Unite (2001) have reported that IPOs of common stock yielded positive short-run raw return and negative longrun market adjusted return.

Fernandez et al. (1993) measured initial return of Spanish IPOs and analysed the effect of age of the firms and industry on IPOs return. On the basis of a sample of 85 IPOs floated during 1985 to 1990, they reported average initial return of $11 \%$ for Spanish IPOs on first trading day. The study showed highest initial return of $28.8 \%$ in case of IPOs of energy and chemical industry and lowest initial return of $6.7 \%$ in case of IPOs of food and agriculture industry. The study found no relationship between the age of the firm and degree of underpricing. The dependence of return, both initial and after market, on the age of the firm was statistically tested with the help of regression analysis and in both cases found insignificant relationship at reasonable confidence levels.

Kim et al. (1995) conducted a study to investigate the role of information disclosed through the prospectuses by the issuer firms on the market price of shares. Taking a sample of 260 IPOs listed on Korea Stock Exchange during the period of January 1985 to March 1990, they found that the market price was significantly affected by financial variables such as earning per share (EPS), offer size, industry prospects and offer type during the period of study. They also reported that the market price was more closely associated with these financial variables after the liberalisation of IPO pricing policy by the Korean Government in 1988 than it was before the liberalisation. The researchers also highlighted the importance of financial variables contained in the prospectus for the pricing of IPO in the new issues market where information about the issuers firms was not easily available.

Indian Studies: During the last two decades, a considerable research work has been conducted to study different aspects of Indian Primary Capital Market. Gupta (1981) measured the rates of return on equities in the Indian capital market for a sample of 276 companies over a period of 16 years from 1961 to 1976 and found that about $20 \%$ equity returns for various holding periods were negative. Gujarathi (1987) examined the initial performance of new issues in India by taking a sample of 98 issues floated during January 1970 to December 1978. On the basis of risk adjusted return, he concluded that investors in new issue market in 1970' earned an extra normal return of nearly $2.5 \%$ per week after accounting for risk. Shah (1995) reported the presence of average underpricing of $105.6 \%$ in Indian primary market on the basis of a large sample of IPOs for 1991-95. Baral (1997) conducted a study on 'Pricing of Initial Public Offerings' to examine the short-run and long-run performance of IPOs. Based on a sample of 3047 IPOs between 1993 to 1997, he reported that the investors obtained abnormally high return in the short-run and negative return in the long-run. Madhusoodanan and Thiripalraju (1997) examined the impact of issue size on the extent of underpricing in their study on Indian IPOs. They found that the highest return was provided by very small issues of the size of less than Rs. 1 crore followed by the issues of the size of less than Rs. 2 crore and medium sized issues between Rs. 5 crore to Rs. 10 crore provided minimum return on listing day.

Ghosh (2004) investigated the boom and slump phases in Indian primary market and examined the relationship between underpricing and age of the Issuer Company as well as size of the issue. Taking a sample of 1842 IPOs which got listed on BSE during January 1993 to March 2001 and after applying ordinary least square (OLS) regression, the study reported less underpricing during boom (hot) period compared to slump period in the Indian IPO market. The researcher found that the age of the issuer company could not explain the variation in the initial return. In the views of the 
scholar, this might be because of the fact that most of the companies that went public during the last decade were young with average age of 7.5 years and Indian investors did not frame their opinion about the viability of a company from its age profile. Considering underpricing as dependent variable and the issue size as the independent variable, the study revealed that the regression coefficient of size was negative but significant at 1 percent level which meant that underpricing was less for issues that collected large amount from the public than the smaller issues.

Need for the Present Study: It emerges from review of literature that the major research work carried on primary capital market focussed on measuring the initial return of IPOs and to evaluate the short-run and long-run performance of IPOs in different countries. No research study has so far been conducted to measure the impact of offer document disclosures on equity return in India. As already stated, the important financial disclosures like turnover, total assets, net worth, EPS, book value, promoter's stake in post-issue capital and dividend history of the issuer company influence the investment decision of the investing public, hence the impact of these disclosures on equity return needs to be examined. Industry-wise classification of capital raised through primary market during a period of eleven years from 199394 to 2003-04 amounted to Rs. $1,24,815$ crore with 4,161 public issues; of which about $49 \%$ resources have been mobilized by companies belonging to banking, finance and investment, information technology, pharmaceutical and chemical goods industry (SEBI's Handbook of Statistics on the Indian Securities Market, 2006). Further, a large number of 1,891 (45.44\%) public issues have been floated by companies belonging to above mentioned industries during the same period. These statistics reveal that the companies belonging to above stated industries mobilised substantial amount of resources from the investors through public issues. So, the impact of important offer document disclosures on equity issues return of these industries should be examined besides measuring the return to investors. This is an unexplored area of research and to fill the gap, the present study has been conducted.

\section{OBJECTIVES OF THE STUDY}

The present study has been undertaken to meet the following specific objectives.

1. To measure the impact of offer document disclosures on equity return in India by taking equity issues return as dependent variable and disclosures regarding turnover, total assets, net worth, Earning Per Share (EPS), Book Value (BV), percentage of dividend paid, age, promoters' stake in post-issue capital and issue size as explanatory variables of equity issues return belonging to 5 different industries namely Banking, Finance and Investment, Information Technology (IT), Pharmaceuticals and Chemical goods.

2. To evaluate the performance of equity issues of Banking, Finance and Investment, Information Technology, Pharmaceutical and Chemical goods industry on the basis of the average return.

\section{DATABASE AND RESEARCH METHODOLOGY}

This section of the article deals with sample size, period of study and database of the study. Besides this, it explains the formulae constructed to measure equity return and technique applied for the analysis of the data to draw meaningful conclusions therefrom.

\section{Sample size and Period of Study}

The study is based on a sample of 97 public equity issues of companies belonging to 5 different industries, each issue of the size of Rs. 10 crore or more, which were floated during a period of 12 years from 1992-93 to 2003-04. The industry-wise break-up of the issues is given below:
1. Banking Industry
20 issues
2. Finance \& Investment Industry
20 issues
3. Information Technology Industry
20 issues
4. Pharmaceutical Industry
17 issues
5. Chemical Goods Industry
20 issues Total
97 issues

While selecting the sample for the present study, the following criteria were adopted. 
- Public equity issues are the first issues of the closely held unlisted companies which made disclosures in their respective offer document regarding turnover, total assets, net worth, Earning Per Share (EPS), Book Value (BV) and percentage of dividend paid for at least 3 years preceding the year of public offer.

- The issue size should be of at least Rs. 10 crore or more.

- The equity shares offered through offer document got listed on Bombay Stock Exchange.

- The share price data of the equity shares of the sampled companies was available at 6 points of time chosen for measurement of return namely on first trading day, after 3 months, 6 months, 1 year, 2 years and 3 years from the first trading day of the issues on Bombay Stock Exchange.

- No sampled company was delisted during return measurement period.

\section{DATABASE OF THE STUDY}

The required data has been collected from the offer documents (hard copies) of the issuer companies, different issues of the financial daily 'The Economic Times' and Bombay Stock Exchange web site: www.bseindia.com. In addition, the data regarding date of listing of equity shares and record dates of bonus issues, rights issues and stock-splits by companies under study have been collected from listing department of Bombay Stock Exchange.

\section{Measurement of Equity Return}

Equity issues return has been found out with the help of following steps.

\section{Measurement of Simple Rate of Return}

First of all, simple rate of return has been found out at 6 points of time for all 97 public equity issues by applying the formula:

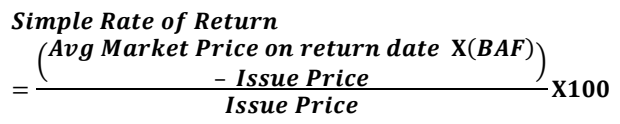

Average Market Price was found out by averaging the high and low market price on return measurement date. If a return measurement date happens to be Sunday or no trading day on Bombay Stock Exchange, then market price on the next trading day has been taken for measurement of simple rate of return.

In order to find out the real return from equity investment made in primary capital market, simple rate of return has been adjusted for the effect of post-listing bonus issue, rights issue and stock-split decision, if any, made by the sampled companies during return measurement period i.e. within 3 years from first trading day of the issue. Adjustment for these corporate actions has been done as follows:

\section{Adjustment for Post-Listing Bonus Issue}

The adjustment of bonus shares was made by multiplying the 'Bonus Adjustment Factor' (BAF) with average market price calculated on return measurement dates subsequent to bonus issue record date. The 'Bonus Adjustment Factor' (BAF) was found out by dividing total holdings after bonus issue with holdings before bonus issue. Gupta (1981) followed the same methodology in his study on 'Rates of Return on Equity'. To explain the adjustment, suppose a company has made a bonus issue in the ratio of 1 bonus share for every 2 shares held then bonus adjustment factor would be $1.5\{(2+1) / 2\}$. The adjusted rate of return after bonus issue would be:

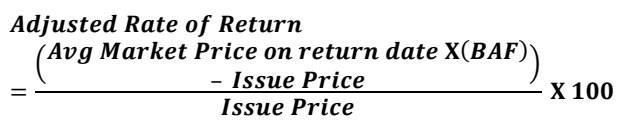

\section{Adjustment for Post-Listing Rights Issue}

If a company has made rights issue to its shareholders, it certainly affects the equity return obtained after the record date of rights issue. To incorporate the effect of rights issue in equity return, method followed by Gupta (1981) has been used. To carry out the rights issue adjustment, he assumed that a shareholder has to first sell his right and then immediately reinvest the proceeds in the shares of the same company at ex-market price. In this way, the cum-right market price (market price before the record date for rights issue) is comparable with ex-right market price (market price after the record date of rights issue) of shares. The whole adjustment is explained with 
help of an example. Suppose a company made a rights issue in the ratio of 1 right share for every 2 shares held @ Rs.100 per share and the cum-right market price was Rs.175 per share. The ex-right market price comes out Rs. $150\{(175 \times 2+100$ x $1) /(2+1)\}$ or (Rs.450/3). In this way, the value of right is Rs.25 \{cum-right market price (Rs. 175) ex-right market price (Rs.150)\}. The shareholder would realise Rs.25 from the sale of his right and would buy $1 / 6(25 / 150)$ share at ex-right market price. His holdings in the company will increase from 1 share to $7 / 6(1+1 / 6)$ shares. The market price of his holdings before the rights issue was Rs. 175 and after the rights issue would also be Rs.175 (150 x 7/6). So $7 / 6$ is the 'Rights Adjustment Factor' (RAF). Following the same method and procedure, the ex-market price of the shares of sampled companies which made rights issue during return period has been adjusted. So, adjusted rate of return after rights issue record date would be:

\section{Adjusted Rate of Return}

$=\frac{\left(\begin{array}{c}\text { Avg Market Price on return date } \mathrm{X}(\mathrm{RAF}) \\ - \text { Issue Price }\end{array}\right)}{\text { Issue Price }} \times 100$

\section{Adjustment for Post-Listing Stock-Split: A} stock-split reduces the face value of a share and increases the number of outstanding shares without altering the company's equity. But a stock-split decision increases the supply of shares in the market. Market price of shares falls after the stock-split more or less in the same proportion in which number of shares increases as a result of stock-split. In the present study, equity return has been adjusted for stock-split. The effect of stocksplit has been incorporated in computation of return with the help of 'Stock Split Adjustment Factor' (SSAF). Equity return becomes comparable only after such adjustment is made. Stock-split adjustment can be made with the help of following formula:

$$
\begin{aligned}
& \text { Stock }- \text { Split Adjustment Factor } \\
& =\frac{\text { Total holdings after stock }- \text { split }}{\text { Holding before stock }- \text { split }}
\end{aligned}
$$

'Stock Split Adjustment Factor' (SSAF) has been multiplied with average market price for all return computations after book closure date for the purpose of stock-split. To explain this adjustment, suppose Mr. X holds 1 share of nominal value of Rs. 10 each in Y Ltd. The company splits its equity shares in the ratio of 2 shares of Rs. 5 each for every 1 share of Rs.10 each held in the company. With this split, the holdings of Mr. X in the company will increase from 1 share to 2 shares and 'Stock Split Adjustment Factor' will be 2 $(2 / 1)$. The market price after the stock-split should be multiplied with 'Stock Split Adjustment Factor' so that market price before the stock- split becomes comparable with the market price after the stock-split. On this basis, the average market price of the shares has been adjusted in case of those sampled companies which implemented stock-split decision during the return period under study i.e. within 3 years from first trading day. The adjusted rate of return after stock-split would be:

\section{Adjusted Rate of Return}

$=\frac{\left(\begin{array}{c}\text { Avg Market Price on return date } \mathrm{X}(\mathrm{SSAF}) \\ - \text { Issue Price }\end{array}\right)}{\text { Issue Price }} \times 100$

5. Finding out Average Adjusted Rate of Return: After finding out adjusted rate of return (simple rate of return adjusted for the effect of bonus issue, rights issue and stock-split) at 6 points of time (on FTD, after 3 months, 6 months, 1 year, 2 years and 3 years from FTD), the average adjusted rate of return has been found out with the help of following formula:

\section{Average Adjusted Rate of Return $=\underline{\text { Adjusted Rate of Return at Six Points of Time }}$}

Before finding out the average, the simple rate of return on first trading day and after 3 and 6 months from FTD has been annualized with the help of following formulae:

First Trading Day (FTD)Return(On annual basis)

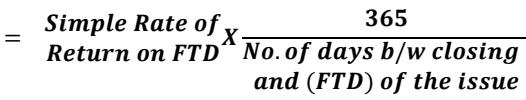

Return after 3 months (On annual basis) $=$ Simple Rate of Return after 3 months $X \frac{12}{3}$ Return after 6 months (On annual basis) = Simple Rate of Return after 6 months $\frac{12}{6}$ 
Average of adjusted rate of return found out was termed as 'Average Adjusted Rate of Return' and called equity return/market equity return in this study.

Technique used for Analysis of the Data: The Linear Multiple Regression Analysis has been applied to find out the individual and combined impact of selected explanatory variables on equity return, dependent variable in the study. The explanatory variables taken from offer documents of the sampled companies are turnover, total assets, net worth, earning per share, net asset value/ book value, percentage of dividend paid, age of the issuer company, promoters' stake in post issue capital and issue size. The figures of turnover, total assets, net worth, earning per share, net asset value/ book value and percentage of dividend paid have been taken on average basis, based on the figures for 3 years preceding the year of issue, while the values of other variables are taken in absolute figures. If $\mathrm{Y}$ stands for market equity return, $X_{1}$ for average turnover (AVG.TO), $\mathrm{X}_{2}$ for average total assets (AVG.TA), $\mathrm{X}_{3}$ for average net worth (AVG.NW), $X_{4}$ for average earning per share (AVG.EPS), $X_{5}$ for average book value/net asset value (AVG.BV/NAV), $\mathrm{X}_{6}$ for average percentage dividend paid (AVG.DP), $\mathrm{X}_{7}$ for age of issuer company, $\mathrm{X}_{8}$ for promoters' stake in post-issue capital (PS) and $\mathrm{X}_{9}$ for issue size (IS) then the regression equation takes the form of:

$Y=b_{0}+b_{1} x_{1}+b_{2} x_{2}+b_{3} x_{3}+b_{4} x_{4}+b_{5} x_{5}+b_{6} x_{6}+$ $b_{7} x_{7}+b_{8} x_{8}+b_{9} x_{9}$

Where Y represents market equity return, the dependent variable in the model, $b_{o}$ is the intercept, the model predicted value of the dependent variable when the value of every predictor (explanatory variable) is equal to zero. $\mathrm{X}_{1}$ to $\mathrm{X}_{9}$ are explanatory variables and $\mathrm{b}_{1}$ to $\mathrm{b}_{9}$ are regression coefficients of the explanatory variables in the model. The significance of the coefficients of explanatory variables has been tested by comparing the calculated t-values with the tabulated $\mathrm{t}$-values at $(\mathrm{N}-\mathrm{K})$ degrees of freedom (where $\mathrm{N}$ stands for the number of equity issues and $\mathrm{K}$ for the total number of parameters to be estimated including the intercept term) and the results have been tested at $0.01 \& 0.05$ level of significance for two tailed tests. The overall significance of the regression equation i.e., significance of $\mathrm{R}^{2}$ __ a measure of goodness of fit was computed to see the percentage of variations in the dependent variable explained by explanatory variables in the model. The significance of $\mathrm{R}^{2}$ has also been checked by applying ' $F$ statistic'. Adjusted coefficient of determination (Adj. $\mathrm{R}^{2}$ ) has also been calculated. Industry-wise performance of equity issues has been evaluated on the basis of the industry average return at 6 points of time selected for measurement of return in the study. For this purpose, average adjusted rate of return of all the equity issues belonging to an industry was found out and then industry average return was found out with the help of following formula.

\section{Industry Average Return \\ Total of Average Adjusted Rate of Return of \\ Equity Issues of an Industry \\ Number of Equity Issues of the Industry}

\section{Results of Regression Analysis and Interpretation}

The results of Linear Multiple Regression Analysis have been presented in Table 1. The Industry-wise interpretation of these results is given below.

Banking Industry: A glance at table 1 shows that $\mathrm{R}^{2}$ of the fitted regression equation in case of equity issues of banking industry is .753 and significant at 5 percent level. It shows that the explanatory variables covered by the study explained about $75 \%$ variation in market equity return in case of issues of banking industry. The regression coefficients of average turnover, average total assets, average net worth, average earning per share, average dividend paid and age of the company are positive but non-significant. It means that these disclosures have shown positive impact on market equity return but their impact is statistically non-significant at 1 percent and 5 percent levels. Disclosure regarding book value, promoters' stake in post-issue capital and issue size failed to establish their impact on equity return as their coefficients are not only negative but insignificant also.

Finance and Investment Industry: In case of equity issues of the companies belonging to finance and investment industry, the coefficient of 
average turnover is not only positive with a value of 2.52 but also significant at 5 percent level. It signifies that equity return increased by 2.52 percent due to increase in average turnover by Rs. 1 crore in case of equity issues of finance and investment industry. The regression coefficients of age, issue size, average earning per share and average book value are positive with values of 6.3 , $1.18, .3$ and .92 respectively but are insignificant at 1 percent and 5 percent levels. The explanatory variables of dividend paid, promoters' stake in post-issue capital, net worth and total assets could not establish its impact on equity return because their coefficients are not only negative but insignificant also. The coefficient of determination, $\mathrm{R}^{2}$, indicates that the explanatory variables under study explained 72.3 percent variation in equity return in case of issues of finance and investment industry. The disclosure of net asset value which is considered as an important fund mobiliser factor in the issues of these companies but the results of the study could not establish any association between net asset value of sampled finance and investment companies and the average adjusted rate of return obtained by the investors.

Information Technology Industry: As revealed by Table 1 , the coefficient of determination $\left(R^{2}\right)$ explained 40.2 percent variation in equity return due to explanatory variables covered by the study in case of equity issues of IT industry but this explained variation is insignificant at 1 percent and 5 percent levels. It seems that the equity return in case of IT industry is dependent more on other factors not covered by the study. Though, the coefficients of average dividend paid, issue size, average net worth and book value have shown positive impact on equity return with values of 28.46, 1.28, 1.04 and .39 but they are insignificant at reasonable levels. The disclosure of turnover, total assets, earnings per share, age and promoters' stake in post-issue capital in the offer documents of IT companies could not explain any variation in equity return as their coefficients are negative as well as insignificant.

Pharmaceutical Industry: The $\mathrm{R}^{2}$ of fitted regression equation in case equity issues of pharmaceutical industry is high at 81.1 percent but insignificant at 1 percent and 5 percent levels. It shows that the explanatory variables of the study have explained 81.1 percent variation in average adjusted rate of return but this high percentage of variation is insignificant from statistical angle. But the regression coefficients of average earning per share and average net worth are not only positive with 29.83 and 16.84 values but are significant at 5 percent level. These disclosures have established theirlargest impact on equity return from public issues of pharmaceutical industry. But the coefficients of average turnover, age and percentage of dividend paid are positive but statistically insignificant. Further, the disclosure of book value, total assets, promoters' stake in post-issue capital and issue size could not establish their impact on average adjusted rate of return because their coefficients are not only negative but insignificant also.

\section{Chemical, Plastic and Rubber Goods Industry}

In case of equity issues of chemical, plastic and rubber goods industry, the $\mathrm{R}^{2}$ explained 57.5 percent variation in equity return as a result of the independent variables taken in the study but this explained variation is statistically insignificant at reasonable levels. The regression coefficients of promoters' stake in post-issue capital, average turnover, average total assets and net asset value have shown some impact with positive values but are found insignificant. The coefficients of average net worth, earnings per share, percentage of dividend paid, age and issue size could not explain any variation in market equity return of chemical, plastic and rubber goods industry because their values are both negative as well as insignificant.

As this is the first study which has examined the impact of offer document disclosures on equity return in India, no other study surfaced during review of literature with which these findings can be compared. The individual impact of age on underpricing was examined by Fernandez et al. (1993) taking sample of Spanish IPOs and by Ghosh (2004) looking at Indian IPOs. The findings of the present study reaffirm their findings that no relationship exists between the age of the issuer company and the return/underpricing. 
Table 1

Impact of Offer Document Disclosures on Average Adjusted Rate of Return of Equity Issues of Different Industries - Results of Linear Multiple Regression Analysis

\begin{tabular}{|c|c|c|c|c|c|c|c|c|c|c|c|c|c|c|c|}
\hline \multicolumn{6}{|c|}{ Offer Document Disclosure Variables --.-> } & \multirow[b]{2}{*}{$\begin{array}{l}\text { AVG. } \\
\text { TURN } \\
\text { OVER }\end{array}$} & \multirow[b]{2}{*}{$\begin{array}{l}\text { AVG. } \\
\text { TA }\end{array}$} & \multirow[b]{2}{*}{$\begin{array}{l}\text { AVG. } \\
\text { NW }\end{array}$} & \multirow[b]{2}{*}{$\begin{array}{l}\text { AVG. } \\
\text { EPS }\end{array}$} & \multirow[b]{2}{*}{$\begin{array}{l}\text { AVG. } \\
\text { BV }\end{array}$} & \multirow[b]{2}{*}{$\begin{array}{l}\text { AVG. } \\
\text { DP }\end{array}$} & \multirow[b]{2}{*}{ AGE } & \multirow[b]{2}{*}{ PS } & \multirow[b]{2}{*}{ IS } & \multirow[b]{2}{*}{$\mathbf{N}$} \\
\hline S.No & Type of Industry & $\mathbf{R}^{2}$ & $\begin{array}{l}\text { Adj } \\
\mathbf{R}^{2}\end{array}$ & $\begin{array}{l}\text { F- } \\
\text { Value }\end{array}$ & \begin{tabular}{|l|} 
Reg. \\
Coeff. \& \\
t-values
\end{tabular} & & & & & & & & & & \\
\hline \multirow[t]{2}{*}{1} & \multirow[t]{2}{*}{ Banking } & \multirow[t]{2}{*}{$75.3 * *$} & \multirow[t]{2}{*}{53} & \multirow[t]{2}{*}{3.38} & \begin{tabular}{|l|} 
Reg. \\
Coeff. \\
\end{tabular} & $.059^{\mathrm{NS}}$ & $.001^{\mathrm{NS}}$ & $.01^{\mathrm{NS}}$ & $41.3^{\mathrm{NS}}$ & $6.34^{\mathrm{NS}}$ & $.25^{\mathrm{NS}}$ & $.12^{\mathrm{NS}}$ & $-1.91^{\mathrm{NS}}$ & $-\overline{1.71^{\mathrm{NS}}}$ & 20 \\
\hline & & & & & t-values & 0.57 & 0.11 & 0.1 & 1.95 & -1.18 & 0.03 & 0.12 & -0.61 & -1.44 & \\
\hline \multirow[t]{2}{*}{2} & \multirow{2}{*}{$\begin{array}{l}\text { Finance } \\
\text { Investment }\end{array}$} & \multirow[t]{2}{*}{$72.3 * *$} & \multirow[t]{2}{*}{47.4} & \multirow[t]{2}{*}{3.02} & $\begin{array}{l}\text { Reg. } \\
\text { Coeff. }\end{array}$ & $2.52 * *$ & $.069^{\mathrm{NS}}$ & $14^{\mathrm{NS}}$ & $.30^{\mathrm{NS}}$ & $.92^{\mathrm{NS}}$ & $4^{\mathrm{NS}}$ & $6.30^{\mathrm{NS}}$ & $5^{\mathrm{NS}}$ & $.18^{\mathrm{NS}}$ & 20 \\
\hline & & & & & t-values & 2.35 & -0.39 & -0.63 & 0.53 & 0.89 & -2.46 & 0.39 & -0.83 & 0.36 & \\
\hline \multirow[t]{2}{*}{3} & \multirow{2}{*}{$\begin{array}{l}\text { Information } \\
\text { Technology }\end{array}$} & \multirow[t]{2}{*}{$40.2^{\mathrm{NS}}$} & \multirow[t]{2}{*}{0} & \multirow[t]{2}{*}{0.75} & \begin{tabular}{|l|} 
Reg. \\
Coeff.
\end{tabular} & $-0.46^{\mathrm{NS}}$ & $\begin{array}{l}- \\
1.71^{\mathrm{NS}}\end{array}$ & $1.04^{\mathrm{NS}}$ & $-3.26^{\mathrm{NS}}$ & $.39^{\mathrm{NS}}$ & $28.46^{\mathrm{NS}}$ & $26.4^{\mathrm{NS}}$ & $-\overline{12.29^{\mathrm{NS}}}$ & $1.28^{\mathrm{NS}}$ & 20 \\
\hline & & & & & t-values & -0.16 & -0.82 & 1.58 & -0.98 & 0.75 & 1.53 & -0.94 & -1.8 & 1.95 & \\
\hline \multirow[t]{2}{*}{4} & \multirow[t]{2}{*}{ Pharmaceuticals } & \multirow[t]{2}{*}{$81.1^{\mathrm{NS}}$} & \multirow[t]{2}{*}{56.9} & \multirow[t]{2}{*}{3.34} & $\begin{array}{l}\text { Reg. } \\
\text { Coeff. }\end{array}$ & $9.79^{\mathrm{NS}}$ & $9.86^{\mathrm{NS}}$ & $16.84 * *$ & $29.83 * *$ & $-\overline{19.4^{\mathrm{NS}}}$ & $.72^{\mathrm{NS}}$ & $8.09^{\mathrm{NS}}$ & $-0.61^{\mathrm{NS}}$ & $4.30^{\mathrm{NS}}$ & 17 \\
\hline & & & & & t-values & 2.1 & -1.81 & 3.2 & 3.3 & -3.66 & 0. & 2.26 & -0.24 & -3.96 & \\
\hline & \multirow{2}{*}{$\begin{array}{l}\text { Chemicals, Plastic } \\
\text { and Rubber Goods }\end{array}$} & \multirow[t]{2}{*}{$57.8^{\mathrm{NS}}$} & \multirow[t]{2}{*}{19.8} & 1.52 & $\begin{array}{l}\text { Reg. } \\
\text { Coeff. }\end{array}$ & $.83^{\mathrm{NS}}$ & $.29^{\mathrm{NS}}$ & $-2.02^{\mathrm{NS}}$ & $-0.42^{\mathrm{NS}}$ & $.60^{\mathrm{NS}}$ & $-2.77^{\mathrm{NS}}$ & $1.85^{\mathrm{NS}}$ & $1.02^{\mathrm{NS}}$ & $2.43^{\mathrm{NS}}$ & \\
\hline & & & & & t-values & 1.16 & 0.23 & -0.5 & -0.3 & 1.58 & -0.66 & -0.55 & 0.39 & -1.31 & \\
\hline
\end{tabular}

Note: (i) * and ** denote significance at 1 percent and 5 percent levels for t-values of regression coefficient and for F-values of coefficient of determination respectively. NS stands for non-significant. (ii) Adjusted Rate of Return has been computed.

Source: Compiled from Offer Documents of Companies, BSE website and Economic Times.

Industry-wise Performance of Equity Issues

The performance of equity issues has been evaluated on the basis of average return at six points of time. Table 2 reveals that the equity investors have obtained average return invarying percentages from the equity issues of banking, finance and investment, information technology, pharmaceutical and chemical goods industries at different points of time covered by the study.

Table 2

Average Return from Equity Issues of Different Industries

\begin{tabular}{|c|c|c|c|c|c|c|}
\hline \multirow{2}{*}{ Industry } & \multicolumn{6}{|c|}{ Points of Time on/after FTD } \\
\hline & FTD* & 3 Months* & 6 Months* & 1 Year & 2 Years & 3 Years \\
\hline 1.Banking Industry & 2035 & 2815 & 3335 & 5605 & 14405 & 10005 \\
\hline $\mathrm{N}=20$ & 20.35 & 28.15 & 33.35 & 56.95 & 144.95 & | 199.95 \\
\hline 2.Finance and Investment Industry & 207 & 2085 & 2715 & 21 & -295 & -5815 \\
\hline $\mathrm{N}=20$ & & & & & & \\
\hline 3.Information Technology (IT) Industry & 643 & 827 & 678 & 12045 & 3955 & 763 \\
\hline $\mathrm{N}=20$ & 04.3 & 82.1 & $0 / .8$ & 120.45 & 39.53 & 10.3 \\
\hline 4.Pharmaceutical Industry & 2788 & 3118 & 2482 & 44 & 1250 & 4224 \\
\hline $\mathrm{N}=17$ & 21.88 & 31.18 & 24.82 & 44 & 12.59 & 42.24 \\
\hline 5. Chemical, Plastic \& Rubber Goods Industry & 35.3 & 36.85 & 32.55 & 2.85 & -43.15 & -38.45 \\
\hline 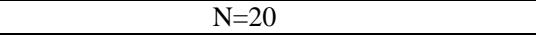 & & & & & & \\
\hline
\end{tabular}

Note: (i) * Signifies Average Return in absolute figures, and not on annual basis.

Source: Compiled from Offer Documents of Companies, BSE website and Economic Times. 
The equity investors obtained highest average return of $64.3 \%$ from the equity issues of information technology industry and minimum average return of $20.35 \%$ from the equity issues of banking industry on first trading day. Average return of $35.3 \%, 27.88 \%$ and $20.7 \%$ was reaped by the original allotees from the equity issues of chemical goods, pharmaceutical and finance and investment industries respectively on first trading day of the issues on Bombay Stock Exchange, as revealed by Table 2. The equity issues of information technology industry continued to cheer the investors with an average return of $82.7 \%, 67.8 \%$ and $120.45 \%$ after 3 months, 6 months and 1 year from first trading day respectively. The investors which disposed off their allotted shares of sampled IT companies after 2 and 3 years from FTD could not get very high return and they had to satisfy themselves with an average return of $39.55 \%$ and $76.30 \%$ respectively. The return percentages shown in Table 2 confirm that the equity issues of banking industry performed well with the passage of time as the average return increased from $20.35 \%$ on FTD to $28.15 \%, 33.35 \%, 56.95 \%, 144.95 \%$ and $199.95 \%$ after 3 months, 6 months, 1 year, 2 and 3 years respectively from FTD. The study finds that holding the shares of banking companies for longer period proved a right decision of the investors. Table 2 highlights that the performance of equity issues of pharmaceutical industry remained inconsistent as the average return could not follow any trend during return measurement period under study. At each subsequent point of time, the average return showed reverse trend than the return at preceding point of time. It may be due to the reason that market could not form a consistent and strong view of the equity of pharmaceutical industry with the results that investors obtained return in varying percentages at different points of time during the period under study.

If we look at the statistics of Table 2, the average return from the equity issues of chemical, plastic and rubber goods industry improved after 3 months at $36.3 \%$ and remained more or less stable at $32.55 \%$ after 6 months from first trading day and thereafter the return fell down to $2.85 \%$ after 1 year, converted into negative return of $43.15 \%$ and $38.45 \%$ after 2 and 3 years from first trading day. It means that the average return was good up to a short period of 6 months from FTD but these issues disappointed the investors with negative return in the long-run. In comparison to average return obtained by the investors from the issues of banking, IT, pharmaceutical and chemical goods industry, the equity issues of finance and investment industry provided less initial return and highest negative return of $58.15 \%$ to the investors after 3 years from first trading day. It means that the equity investors lost almost $60 \%$ of their original investment after 3 years in case of equity issues of finance and investment industry.

\section{FINDINGS \& CONCLUSION}

The results of the study led to the conclusion that the offer document disclosures under study explained significant amount of variation in equity return in case of equity issues of banking as well as finance and investment industry. Disclosure of turnover established its largest impact on equity return in case of issues of finance and investment industry. Likewise, disclosure of net worth and EPS positively affected the equity return in case of equity issues of pharmaceutical industry as their regression coefficients are significant at 5 percent level. The study found that the disclosure of financial variables like EPS in case of banking and finance and investment industry; BV in case of finance and investment, IT and chemical goods industry; percentage of dividend paid in case of banking, IT and pharmaceutical industry; turnover in case of banking, pharmaceutical and chemical goods industry; and total assets in case of banking and chemical goods industry positively affected the equity return but their regression coefficients have been found insignificant at reasonable levels. Except this, other explanatory variables failed to explain the variation in equity return as their regression coefficients are negative as well as non-significant. Though, SEBI has streamlined the disclosure requirements in order to protect the interests of the investors in the market but Indian capital markets have not yet reached at the level where investors realize a return which is largely supported by offer document disclosures. There is an urgent need to integrate the market equity 
return with the financial parameters of the issuer companies which form part of important offer document disclosures.

The industry-wise performance of equity issues measured on the basis of average return revealed that the issues of banking industry proved more beneficial to the long term investors, who disposed off their original allotment after two or three years from first trading day. It implies that the issues of banking industry should be preferred by the investors for long term investment. The equity issues of IT industry provided maximum return up to one year period from first trading day and thereafter the average return has declined which indicates that the investment in the equity issues of IT industry is more beneficial in the short-run than in the long-run period. In comparison to the average return from the equity issues of industries covered by the study, the issues of finance and investment industry provided less initial return and highest negative return to the investors after three years from first trading day. The results of the study suggest that the equity issues of finance and investment industry are not safe for long term investors and hence should be avoided.

\section{SCOPE FOR FURTHER STUDY}

The findings of this study are based on a sample of 97 public equity issues of the size of Rs. 10 crore and more belonging to five industries and floated during a period of 12 years from 1992-93 to 2003-04. The entire aspect of determinants of equity return should be further examined by increasing the sample size and period of study. In addition, the impact of market index return and Foreign Institutional Investors' (FIIs) participation in public issues on rate of equity return should also be investigated as these aspects have not been covered by the present study.

\section{REFERENCES}

[1] Akhtar S and Abdul Q (1999), "Price Behaviour of New Issues Listed with Dhaka Stock Exchange", The Asian Economic Review, Vol. 41, No. 2, pp. 235-246.
[2] Arosia R, Giudici G and Paleari, S (2000), "What Drives the Initial Market Performance of Italian IPOs? An Empirical Investigation on Underpricing\& Price Support",available at http://papers. ssrn.com/id241929.pdf

[3] Avadhani V A (2007), Securities Analysis and Portfolio Management, $8^{\text {th }}$ Edition, Himalaya Publishing House, Mumbai.

[4] Baral S K (1997), An Empirical Investigation into Pricing of Initial Public Offerings in India, Unpublished $\mathrm{Ph}$. D. Thesis, Berhampur University, Berhampur, Orissa.

[5] Bhole L M (1995), "The Indian Capital Market at crossroads", Vikalpa, Vol. 20, No. 2, pp. 29-41.

[6] Bombay Stock Exchange (2006), Primer on Capital Markets, An outline on Concepts in Economics, Finance and Capital Markets, BSE Training Institute and Jamnalal Bajaj Institute of Management Studies, Mumbai.

[7] Capital Market (2004), Compendium of Top 500 Companies in India, Capital Market Publishers India Pvt. Ltd, Mumbai.

[8] Datey V S (2007), Corporate Laws \& Secretarial Practice, $7^{\text {th }}$ Edition, Taxmann Publishers, New Delhi.

[9] Fernandez P, Abascal E M and Rahnema A (1993), "Initial Public Offerings: The Spanish Experience", Research Paper No. 243, Research Division, IESE, University of Navarra, Barcelona, Spain, available at http://www.iese.edu/research/pdf./DI-0243

[10] Gangadhar V and Reddy G (2006), "Impact of IPO Scam on Capital Market", Indian Journal of Accounting, Vol. 37, No. 1, pp. 1-8.

[11] Ghosh S (2004), "Boom and Slump Periods in the Indian IPO Market", Reserve Bank of India Occasional Papers, Vol. 25, Nos. 13, pp. 39-56.

[12] Gujarathi M (1987), “Do New Equity Issues Fetch Extra Normal Returns?",Vikalpa, Vol. 12, No. 4, pp. 43-50.

[13] Gujarati D (1985), Basic Econometrics, $5^{\text {th }}$ Edition, Tata McGraw Hill, New Delhi. 
[14] Gupta L C (1981), Rates of Return on Equities: The Indian Experience, Oxford University Press, New Delhi.

[15] Ibbotson R G (1975), "Price Performance of Common Stock New Issues", Journal of Financial Economist, Vol. 2, No. 3, pp. 235-272.

[16] Jain S (2001), "Of, by and for the operators", available at www.india_Seminar.com/2001/502.

[17] Kapdia H (2006), "Indian Capital Market Outlook", Monthly Economic Digest, Vol. 35, No. 12, pp. 16-18.

[18] Khan M Y (2005), Indian Financial System, $4^{\text {th }}$ Edition, Tata McGraw Hill, New Delhi.

[19] Kim J B, Kninsky I and Lee J (1995), "The Role of Financial Variables in the Pricing of Korean Initial Public Offerings", PacificBasin Finance Journal 3, pp. 429-464.

[20] Kooli M (2006), "Reassessing Canadian IPO Underpricing: Evidence from Common Share, Capital Pool Company, and Unit Offerings", in Gregoriou G (edited), Initial Public Offerings: An International Perspective, Burlington, pp. 247-260.

[21] Levis M (1993), "The Long Run Performance of Initial Public Offerings: The U.K. Experience (1980-1988)", Financial Management, Vol. 22, No. 1, pp. 28-41.

[22] Loughran T and Ritter J R (2004), "Why has IPO underpricing changed over time?",Financial Management, Autumn, pp. 5-37.

[23] Loughran T, Ritter J R and Rydqvist (1994), "Initial Public Offerings: International Insights", Pacific-Basin Finance Journal, Vol. 2, No. 2, pp. 165-199.

[24] Madhusoodanan T P and Thiripalraju M (1997), "Underpricing in Indian Public Offerings: The Indian Experience", Vikalpa, Vol. 22, No. 4, pp.17-30.

[25] Pathak B V (2008), The Indian Financial System-Markets, Institutions and Services, $2^{\text {nd }}$ Edition, Pearson Education, New Delhi.

[26] Ritter J R (1984), “The 'Hot Issues' Market of 1980", The Journal of business, Vol. 57, No. 2, pp. 215-240.
[27] Ritter J R (1991), "The Long Term Performance of Initial Public Offerings", The Journal of Finance, Vol. 46, N1, pp. 327.

[28] Roy M K (1999), "Underpricing of IPO in India-A Study of the Behaviour of Market Participants", Prajnan, Vol. 28, No. 2, pp. 171-180.

[29] Securities and Exchange Board of India (1996-97 to 2006-07), Annual Reports, Various Issues, Bandra, East, Mumbai.

[30] Securities and Exchange Board of India (2000 to 2009), Disclosure and Investor Protection Guidelines, Bandra, East, Mumbai, available at www.sebi.gov.in

[31] Securities and Exchange Board of India (2006), Handbook of Statistics on the Indian Securities Market, Bandra, East, Mumbai, available at www.sebi.gov.in

[32] Shah A (1995), "The Indian IPO Market: Empirical Facts", Working Paper, Centre for Monitoring Indian Economy, Bombay, India. June, pp. 1-29, available at http://www.cmie.ernet.in

[33] Singh A (1995), "Equity Price Behaviour in Indian Corporate Sector", Unpublished Ph. D. Thesis, Guru Nanak Dev University, Amritsar.

[34] Singh F (1993), "Capital Issues and Investor Protection", A Research Paper Presented in Indian Commerce Association Conference, December, Kurukshetra University, Kurukshetra.

[35] Singh F (1995), "Liberalisation and Capital Issues", in Batra B S (edited), Globalisation Strategies and Economic Liberalisation, Anmol Publication Pvt. Ltd, New Delhi, pp. 243-249.

[36] Singh P (2003), Investment Management, Security Analysis \& Portfolio Management, $11^{\text {th }}$ Edition, Himalaya Publishing House, Mumbai.

[37] Venkateshwarlu M (2004), "Trends in New Capital Issues by Private Corporate Sector in India", Economic and Political Weekly, Vol. 39, No. 9, pp. 581-586. 


\section{Appendix-I}

List of Companies whose Public Equity Issues are covered in the Study (with Record Dates of Bonus Issue, Rights Issue and Stock Split)

\begin{tabular}{|c|c|c|c|}
\hline $\begin{array}{l}\text { S.N } \\
\text { o. }\end{array}$ & Banking Industry & $\begin{array}{l}\text { S.N } \\
\text { o. }\end{array}$ & Information Technology Industry \\
\hline 1 & Syndicate Bank & 1 & $\begin{array}{llll}\text { Infosys Technologies Ltd. } & \text { (Bonus } & \text { Issue-Ratio } \\
1: 1, \text { Record Date 15-09-94) } & & \\
\end{array}$ \\
\hline 2 & Indian Overseas Bank & 2 & Pertech Computers Ltd. \\
\hline 3 & Andhra Bank Ltd. & 3 & $\begin{array}{l}\text { Sonata Software Ltd. (Stock Split-Ratio 10:1, } \\
\text { Record Date-09-10-2000) }\end{array}$ \\
\hline 4 & Allahabad Bank & 4 & $\begin{array}{l}\text { SQL Star International Ltd.(Rights Issue-Ratio 3:10, } \\
\text { Record Date 21-01-02) }\end{array}$ \\
\hline 5 & Oriental Bank of Commerce & 5 & Kale Consultant Ltd. \\
\hline 6 & Dena Bank & 6 & Compucom Software Ltd. \\
\hline 7 & Bank of Baroda & 7 & Helios \& Matheson Info. Tech. Ltd. \\
\hline 8 & Punjab National Bank & 8 & $\begin{array}{l}\text { HCL Technologies Ltd. (Stock Split-Ratio 2:1, } \\
\text { Record Date-12-12-2000) }\end{array}$ \\
\hline 9 & Union Bank of India & 9 & Software Technology Group Int. Ltd. \\
\hline 10 & Canara Bank & 10 & Zenith Infotech Ltd. \\
\hline 11 & UCO Bank & 11 & Softpro Systems Ltd. \\
\hline 12 & Bank of Maharashtra & 12 & Softsol India Ltd. \\
\hline 13 & Centurion Bank Ltd. & 13 & Aztec Software \& Technology Services Ltd \\
\hline 14 & $\begin{array}{lrr}\text { Federal Bank } & \text { Ltd. } \\
\text { (Rights Issue-Ratio } 1: 2, & \text { Record Date } \\
\text { 31-03-1996) } & & \\
\end{array}$ & 14 & IT \& T Ltd. \\
\hline 15 & IndusInd Bank Ltd. & 15 & Four Soft Ltd \\
\hline 16 & South Indian Bank Ltd. & 16 & $\begin{array}{l}\text { Hughes Software Systems Ltd.(Stock Split-Ratio 2:1, } \\
\text { Record Date 29-09-2000). (New name-Flextronics } \\
\text { Software Systems Ltd) }\end{array}$ \\
\hline 17 & $\begin{array}{l}\text { Industrial Development Bank Of India } \\
\text { (New name-Industrial Development } \\
\text { Bank of India Ltd) }\end{array}$ & 17 & $\begin{array}{l}\text { Geometric Software Solutions Co. } \\
\text { (Stock Split-Ratio 5:1,Record Date-09-08-02) }\end{array}$ \\
\hline 18 & UTI Bank Ltd. & 18 & MRO-TEK Ltd. \\
\hline 19 & $\begin{array}{l}\text { ICICI Banking Corp. Ltd. (New name- } \\
\text { ICICI Bank Ltd) }\end{array}$ & 19 & $\begin{array}{l}\text { I-Flex Solutions Ltd (Bonus Issue-Ratio 1:1, Record } \\
\text { Date-08-09-2003) }\end{array}$ \\
\hline 20 & Bank of India. & 20 & Patni Computer Systems Ltd \\
\hline & Finance \& Investment Companies & & Chemical, Plastic \& Rubber Goods Industry \\
\hline 1 & Blue Blends Finance Limited & 1 & SreeRayalaseema Petrochemicals Ltd. \\
\hline 2 & Apple Credit Corporation Ltd. & 2 & $\begin{array}{l}\text { Pidilite Industries Ltd. (Bonus Issue-Ratio 1:1, } \\
\text { Record Date -05-11-1996) }\end{array}$ \\
\hline 3 & $\begin{array}{l}\text { Ind Bank Merchant Banking Services } \\
\text { Ltd. }\end{array}$ & 3 & 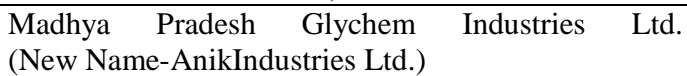 \\
\hline 4 & Bajaj Auto Finance Ltd & 4 & Meta Zinc(India) Ltd. \\
\hline 5 & Prime Securities Ltd. & 5 & Allied Resins \& Chemicals ltd. \\
\hline
\end{tabular}




\begin{tabular}{|c|c|c|c|}
\hline 6 & $\begin{array}{l}\text { Times Guaranty Financials Ltd. } \\
\text { (New name-Times Guaranty Ltd) }\end{array}$ & 6 & Industrial Oxygen Co. Ltd. \\
\hline 7 & LIC Housing Finance Ltd. & 7 & Savita Chemicals Ltd. \\
\hline 8 & Tourism Finance Corp. of India Ltd. & 8 & Hindustan Industrial Chemicals Ltd. \\
\hline 9 & Mafatlal Finance Co.Ltd. & 9 & Metrochem Industries Ltd. \\
\hline 10 & Bhupindra Capital \& Finance Ltd. & 10 & Dai-Ichi Karkari Ltd. \\
\hline 11 & Damania Capital Markets Ltd. & 11 & Ashok Organic Industries Ltd. \\
\hline 12 & GIC Housing Finance Ltd. & 12 & $\begin{array}{l}\begin{array}{l}\text { Themis Chemicals } \\
\text { Medicare Ltd) }\end{array} \\
\text { Men }\end{array}$ \\
\hline 13 & 20th Century Kinetic Finance Ltd. & 13 & Essar Oils Ltd \\
\hline 14 & Escorts Financial Services Ltd. & 14 & Panacea Biotec Ltd. \\
\hline 15 & $\begin{array}{l}\text { Twenty First Century Mgt. Services } \\
\text { Ltd. }\end{array}$ & 15 & Marico Industries Ltd. \\
\hline 16 & $\begin{array}{l}\text { Krishna Texport\& Capital Markets Ltd } \\
\text { (New name-KSL \& Industries Ltd). }\end{array}$ & 16 & Apcotex Lattices Limited \\
\hline 17 & KJMC Financial Services Limited & 17 & $\begin{array}{l}\text { Vision Organics Ltd. (Bonus Issue- Ratio 1:1, Record } \\
\text { Date-28-10-2002) }\end{array}$ \\
\hline 18 & Interface Financial Services Ltd. & 18 & Unimin India Ltd. \\
\hline 19 & Mercury Capital Limited & 19 & $\begin{array}{l}\text { Flex Chemicals Ltd. Rights Issue-Ratio } 3: 2 \text {, Record } \\
\text { Date- } \\
\text { (New name-FCL Technologies \& Products Ltd) }\end{array}$ \\
\hline 20 & PNB Gilts Ltd. & 20 & Indian Petrochemical Corporation Ltd. \\
\hline & Pharmaceutical Industry & 2 & 2 \\
\hline 1 & Earnest Health Care Ltd. & 10 & Elder Pharmaceuticals \\
\hline 2 & IPCA Laboratories Ltd. & 11 & Ajanta Pharma Ltd. \\
\hline 3 & Sun Pharmaceuticals Industries Ltd. & 12 & Surya Pharmaceutical Limited \\
\hline 4 & Recon Ltd. (New name- Wintac Ltd) & 13 & Biocon Ltd \\
\hline 5 & Godavari Drugs Ltd. & 14 & Divi's ' Laboratories Limited \\
\hline 6 & Eupharma Laboratories Ltd. & 15 & SIRIS Ltd. \\
\hline 7 & FDC Ltd. & 16 & AurobindoPharma Ltd. \\
\hline 8 & Glenmark Pharmaceuticals Ltd. & 17 & NatcoPharma Ltd. \\
\hline 9 & Cadila Healthcare Ltd. & & \\
\hline
\end{tabular}

